\title{
A case of conjunctival mucoepidermoid carcinoma in Australia
}

This article was published in the following Dove Press journal:

Clinical Ophthalmology

5 December 2013

Number of times this article has been viewed

\author{
Thomas P Moloney' \\ Tanya Trinh ${ }^{2}$ \\ Jonathon J Farrah ${ }^{1,2}$ \\ 'Department of Ophthalmology, \\ The Royal Brisbane and Women's \\ Hospital, Herston, QLD, Australia; \\ ${ }^{2}$ Department of Ophthalmology, \\ Mater Misericordiae Hospital, \\ South Brisbane, QLD, Australia
}

\begin{abstract}
Conjunctival mucoepidermoid carcinoma is a very rare but highly aggressive conjunctival neoplasm with 42 previously reported cases. We report the case of a 56-year-old male with a left ocular surface squamous neoplasm, which was subsequently treated with excision and autoconjunctival graft. Histopathology of the operative specimen reported a low-grade conjunctival mucoepidermoid carcinoma, and the patient was then treated with an adjunctive course of mitomycin C. On review 10 months after lesion excision, there was no recurrence, and the patient was otherwise well. Due to its rare incidence, difficult clinical diagnosis, and accompanying poor prognosis, conjunctival mucoepidermoid carcinoma should always be considered in the differential diagnosis of conjunctival neoplasms, and full histopathologic examination, including mucin-staining techniques, of all suspicious conjunctival biopsies should occur.
\end{abstract}

Keywords: conjunctiva, neoplasm, pterygium, mitomycin C

\section{Introduction}

First described in 1976, conjunctival mucoepidermoid carcinoma is a rare and highly aggressive variant of conjunctival squamous cell carcinoma which can often require enucleation or orbital exenteration. ${ }^{1,2}$ Histologically, conjunctival mucoepidermoid carcinoma is characterized by cells with squamous differentiation accompanied by variable proportions of mucus-secreting cells. To our knowledge, there have been 42 previously reported cases of conjunctival mucoepidermoid carcinoma, although this probably underestimates the true incidence of the condition due to both clinical and histopathological misdiagnosis. A case of this rare tumor has not been described from Australia, thus we report the first case described from an Australian center and discuss its significance.

\section{Case report}

A 56-year-old man with no background medical history or past ophthalmic history was referred by his general practitioner for a left nasal pterygium. The lesion had been causing ocular irritation and had initially been reviewed by an ophthalmologist 10 years earlier. Since that time, the patient reported that the lesion had slowly grown and his irritation had worsened. On examination, best-corrected visual acuity was 20/20 bilaterally and anterior and posterior segment examinations were unremarkable apart from a left conjunctival lesion. This pearly white lesion was situated on the nasal limbus of the left eye and was circular in shape with a $4 \mathrm{~mm}$ diameter. It was easily mobilized and appeared to be free of any deeper scleral invasion. Overall, the lesion had an appearance in keeping with an ocular surface squamous neoplasm and
Correspondence: Thomas Moloney Department of Ophthalmology, The Royal Brisbane and Women's Hospital, Herston, QLD, Australia Email thomas.moloney@health.qld.gov.au 
wide local excision of the lesion, and reconstruction with a superior autoconjunctival graft was recommended with adjunctive mitomycin $\mathrm{C}$. This uncomplicated procedure was undertaken 3 weeks later.

Histopathology of the operative specimen reported a possible low-grade mucoepidermoid carcinoma, and the specimen was referred to an ophthalmic pathologist who confirmed the diagnosis of low-grade conjunctival mucoepidermoid carcinoma 2 weeks later. Initial hematoxylin and eosin stains were followed by periodic acid-Schiff diastase stains, which confirmed the mucinous components of the lesion (Figures 1 and 2). The specimen showed conjunctival and limbal tissue that was infiltrated with carcinoma at the limbus. It was composed of islands of well differentiated epithelial cells showing both squamous and glandular differentiation with the glandular lumina containing inspissated mucoid material (Figure 1A). No immunohistochemical testing could be conducted on the specimen. A course of $0.04 \%$

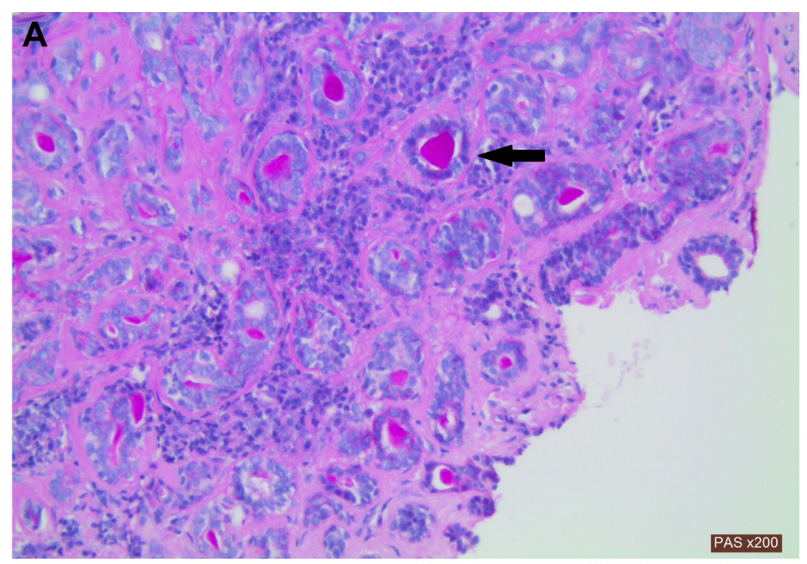

B

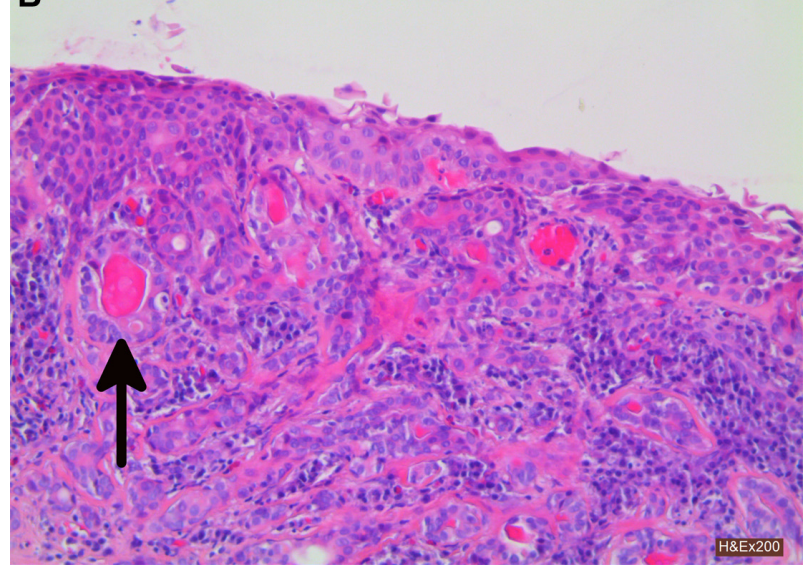

Figure I (A) PAS diastase stain $(\times 200)$ of the lesion confirming pink mucin within numerous ductal structures (arrow). (B) H\&E stain $(\times 200)$ of the lesion showing a predominantly well differentiated population of tubular ductal structures (arrow) and occasional squamoid cords extending beneath the conjunctival surface in mildly fibrotic stroma.

Abbreviations: H\&E, hematoxylin and eosin; PAS, periodic acid-Schiff.

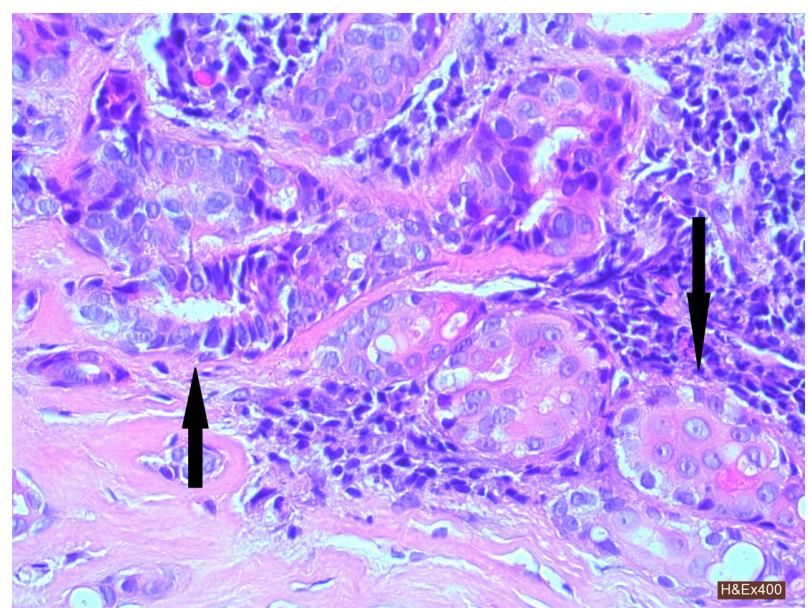

Figure $2 \mathrm{H} \& \mathrm{E}$ stain $(\times 400)$ of the tumor. Ductal structures lined by well differentiated columnar epithelium (up arrow) and solid squamoid nests with abundant eosinophilic cytoplasm (down arrow). There was minimal cytological atypia in either ductal or squamous component.

Abbreviation: H\&E, hematoxylin and eosin

mitomycin $\mathrm{C}$ was prescribed four times a day for 1 week, followed by only ocular lubricants for 1 week, followed then by another week of mitomycin $\mathrm{C}$ four times a day.

On review 2 months after excision, there was no sign of ocular recurrence, and the patient had no ocular symptoms and was systemically well apart from some anxiety related to the possibility of distant spread of the tumor. A subsequent computed tomography scan of the head, neck, chest, abdomen, and pelvis ruled out any signs of regional or distant metastasis. On review 10 months after excision, the patient reported no ocular irritation or other ocular symptoms, had no signs of recurrence of the lesion or lymphadenopathy, and was otherwise systemically well.

\section{Discussion}

In the most recent review on conjunctival mucoepidermoid carcinoma in 2006, Robinson et al reported 22 previously reported cases from the English literature. Now including our own case, several other recent cases, and cases described in the non-English literature, to our knowledge there have been 43 reported cases of conjunctival mucoepidermoid carcinoma. ${ }^{2-17}$ Of these total 43 cases, 26 have been reported from North America, nine from Europe, two each from India and Saudi Arabia, and one each from Nigeria, People's Republic of China, Mexico, and now Australia. Thirty-two cases involved men, and six involved women, with a mean age of 64 years. The reports of five cases did not detail demographic information..$^{5,8,10,16}$ The site of the lesion was the limbal conjunctiva in 26 patients $(67 \%)$, other sites of the bulbar conjunctiva in nine patients $(23 \%)$, and the palpebral 
conjunctiva in four patients $(10 \%)$. These lesions have had variable clinical appearances, from a pearly white bleb/ nodule/mass $(73 \%)$ to a pedunculated lesion $(8 \%)$, a raised conjunctival ulcer $(11 \%)$, and also as an inflamed pterygium $(8 \%) .{ }^{1,2}$ The reports of four cases did not detail lesion site or appearance..$^{4,5,16}$

Conjunctival mucoepidermoid carcinoma has recurred in $25(58 \%)$ of the 43 reported cases. Simple excision has been attempted initially in 23 cases, and recurrence has occurred in 19 of these cases (70\%). Wide local excision has been attempted initially in nine cases, and recurrence has occurred in four of these cases (44\%). Primary exenteration/enucleation has been performed in nine cases (23\%). Overall, exenteration/ enucleation has been required in 28 of the 43 cases $(65 \%)$ for local control of the tumor. In terms of local invasion, intraocular invasion has occurred in 14 cases, and intraorbital invasion has occurred in 14 cases. Intraocular then subsequent intraorbital invasion has occurred in two cases. ${ }^{7,18}$ In terms of advanced orbital invasion, extension into the paranasal sinuses has been described by Margo and Weitzenkorn in 1986, ${ }^{19}$ and one other case from Nigeria has also described complete destruction of the orbit with extension into the maxillary antrum. ${ }^{4}$ Six previous cases have reported distant metastases - five cases with preauricular/cervical lymph node metasta$\operatorname{ses}^{7,15,16,20}$ and one case with nodal/hepatic metastases. ${ }^{1,21}$ Of the five cases with preauriclar/cervical lymph node metastases, only four underwent neck dissection. ${ }^{15,16,20}$ The other patient did not undergo neck dissection and eventually died 6 years after initial presentation - the only known mortality from conjunctival mucoepidermoid carcinoma. ${ }^{7}$

From this brief summary of all reported cases, it is clear that conjunctival mucoepidermoid carcinoma is a highly aggressive tumor which most commonly presents as a limbal mass in elderly men. Although this condition has a historically high preponderance for local invasion if not adequately excised, there is some evidence that a pathologically lower-grade conjunctival mucoepidermoid carcinoma subtype exists which has a lower disposition for local invasion and recurrence. This is illustrated by the slow growth over 10 years of the lesion in our patient without any deep invasion. This could also be illustrated in the recently reported case by Quintas et $\mathrm{al}^{3}$ in 2011, where the patient has had no recurrence after only local excision, cryotherapy, and topical mitomycin C. This management is comparable to the management our patient received, and our patient has also had no recurrence. These cases may support a role for adjuvant cryotherapy and topical mitomycin $\mathrm{C}$, especially in cases of movable in situ, superficial conjunctival mucoepidermoid carcinoma, as previously suggested by Rankin et al. ${ }^{2}$ It is also important to note that this lower-grade subtype could be related to lower-grade salivary gland mucoepidermoid carcinomas, which are associated with MECT1-MAML2 translocation mutations. ${ }^{2}$ Unfortunately, genetic testing of the excised tumor from our patient was unavailable, and we were thus unable to examine this possibility.

Given the difficulty in clinical diagnosis of rare conjunctival mucoepidermoid carcinoma, we recommend that full histopathologic examination of all suspicious conjunctival biopsies should occur, including the use of specialized mucin-staining techniques, including periodic acid-Schiff, Alcian blue, and mucicarmine stains. Immunohistochemical techniques should also be used, especially in cases where histopathological diagnostic uncertainty exists. ${ }^{2}$ If these laboratory measures are not taken, the chance for early diagnosis and treatment could be compromised and could lead to misdiagnosis, possible aggressive local invasion, and even systemic dissemination.

In summary, due to its rare incidence and accompanying poor prognosis, conjunctival mucoepidermoid carcinoma represents both a diagnostic and therapeutic challenge for the ophthalmologist and therefore should always be considered in the differential diagnosis of conjunctival neoplasms.

\section{Disclosure}

The authors report no conflicts of interest in this work.

\section{References}

1. Robinson JW, Brownstein S, Jordan DR, Hodge WG. Conjunctival mucoepidermoid carcinoma in a patient with ocular cicatricial pemphigoid and a review of the literature. Surv Ophthalmol. 2006;51(5):513-519.

2. Rankin JK, Jakobiec FA, Zakka FR, Foster CS. An improved approach to diagnosing and treating conjunctival mucoepidermoid carcinoma. Surv Ophthalmol. 2012;57:337-346.

3. Quintas AM, Fonseca AC, Crujo C, Almeida L, Monteiro-Grillo M. Mucoepidermoid carcinoma of the bulbar conjunctiva - an interventional case report. GMS Ophthalmol Cases. 2011;1:Doc06.

4. Ogun GO, Ogun OA, Bekibele CO, Akang EE. Intraepithelial and invasive squamous neoplasms of the conjunctiva in Ibadan, Nigeria: a clinicopathological study of 46 cases. Int Ophthalmol. 2009;29:401-409.

5. de Albuquerque Alves LF, Fernandes BF, Burnier JV, Zoroquiain P, Eskenazi DE, Burnier MN. Incidence of epithelial lesions of the conjunctiva in a review of 12,102 specimens in Canada (Quebec). Arq Bras Oftalmol. 2011;74(1):21-23.

6. Lacour S, Legeais JM, D’Hermies F, Abenheim A, Renard G, Pouliquen Y. Carcinome mucoepidermoide de la conjunctive avec invasion intraoculaire. A propos d'un cas. [Mucoepidermoid carcinoma of the conjunctiva with intraocular invasion. About one case]. J Fr Ophalmol. 1991;14(5):349-352. French.

7. Dhermy P, Pouliquen Y, Haye C, Parent A. Carcinome muco-epidermoide de la conjontive. Etude Clinique, histologique et ultrastructurale [Mucoepidermoid carcinoma of the conjunctiva. Clinical, histological and ultrastructural study]. J Fr Ophtalmol. 1983;6(6-7):553-563. French. 
8. Cervantes G, Rodriguez A Jr, Gomez Leal A. Squamous cell carcinoma of the conjunctiva: clinicopathological features in 287 cases. Can J Ophthalmol. 2002;37(1):14-19.

9. Kapur R, Sugar J, Edward DP. Conjunctival mucoepidermoid carcinoma: clear cell variant. Arch Ophthalmol. 2005;23:1265-1268.

10. Feng G, Yi Y, Li Y. [777 cases of primary conjunctival neoplasm]. Yan Ke Xue Bao. 1995;11(4):211-215. Chinese.

11. Moulin AP, Hamedani M, Majo F, Schaefer F, Guex-Crosier Y. Mucoepidermoid carcinoma as a masquerade syndrome of scleral melting and granulomatous kerato-uveitis. Kiln Monatsbl Augenheilkd. 2011;228:347-349.

12. Simons BD, Sulewski ME, Frayer WC, et al. A goblet cell-rich variant of conjunctival mucoepidermoid carcinoma. Invest Ophthalmol Vis Sci. 1996;37(3):S245

13. Seitz B, Henke V. Mucoepidermoid carcinoma of the epibulbar conjunctiva with diffuse intraocular epithelial ingrowth. Kiln Monatsbl Augenheilkd. 1995;207:264-265.

14. Rodman RC, Frueh BR, Elner VM. Mucoepidermoid carcinoma of the caruncle. Am J Ophthalmol. 1997;123(4):564-565.

15. Von Domarus D. Mukoepidermoides karzinom der konjunktiva [Mucoepidermoid carcinoma of the conjunctiva]. Kiln Monatsbl Augenheilkd. 1978;173:845-849. German.
16. Johnson TE, Tabbara KF, Weatherhead RG, Kersten RC, Rice C, Nasr AM. Secondary squamous cell carcinoma of the orbit. Arch Ophthalmol. 1997;115:75-79.

17. Albert DM. Mucoepidermoid carcinoma of the conjunctiva with intraocular invasion. Presented at Eastern Ophthalmic Pathology Society meeting, Philadelphia, Oct 1980.

18. Gunduz K, Shields CL, Shields JA, Mercado G, Eagle RC Jr. Intraocular neoplastic cyst from mucoepidermoid carcinoma of the conjunctiva. Arch Ophthalmol. 1998;116:1521-1523.

19. Margo CE, Weitzenkorn DE. Mucoepidermoid carcinoma of the conjunctiva: report of a case in a 36 year-old with paranasal sinus invasion. Ophthalmic Surg. 1986;17:151-154.

20. Hwang IP, Jordan DR, Brownstein S, Gilberg SM, McEachren TM, Prokopetz R. Mucoepidermoid carcinoma of the conjunctiva - a series of three cases. Ophthalmology. 2000;107:801-805.

21. Jastrebski A, Brownstein S, Jordn DR, Gilberg SM. Histochemical analysis and immunohistochemical profile of mucoepidermoid carcinoma of the conjunctiva. Saudi J Ophthalmol. 2012;26:205-210.
Clinical Ophthalmology

\section{Publish your work in this journal}

Clinical Ophthalmology is an international, peer-reviewed journal covering all subspecialties within ophthalmology. Key topics include: Optometry; Visual science; Pharmacology and drug therapy in eye diseases; Basic Sciences; Primary and Secondary eye care; Patient Safety and Quality of Care Improvements. This journal is indexed on

\section{Dovepress}

PubMed Central and CAS, and is the official journal of The Society of Clinical Ophthalmology (SCO). The manuscript management system is completely online and includes a very quick and fair peer-review system, which is all easy to use. Visit http://www.dovepress.com/ testimonials.php to read real quotes from published authors. 